\title{
To Speak Up or Not: A Critical Study of Two Feminist Voices in Light of Women's Empowerment
}

\author{
Abdullah K. Shehabat \\ Department of English Language and Literature, College of Arts, Tafila Technical University, Jordan
}

Received November 25, 2019; Revised July 3, 2020; Accepted July 20, 2020

\begin{abstract}
Cite This Paper in the following Citation Styles
(a): [1] Abdullah K. Shehabat, "To Speak Up or Not: A Critical Study of Two Feminist Voices in Light of Women's Empowerment," Linguistics and Literature Studies, Vol. 8, No. 5, pp. 229 - 237, 2020. DOI: 10.13189/lls.2020.080501.
\end{abstract}

(b): Abdullah K. Shehabat (2020). To Speak Up or Not: A Critical Study of Two Feminist Voices in Light of Women's Empowerment. Linguistics and Literature Studies, 8(5), 229 - 237. DOI: 10.13189/lls.2020.080501.

Copyright@2020 by authors, all rights reserved. Authors agree that this article remains permanently open access under the terms of the Creative Commons Attribution License 4.0 International License

\begin{abstract}
The present paper is a comparative study between two poems: Suad Al-Sabah's They Say (2001) and Anne Bradstreet's The Prologue (1650). The study aims to investigate certain aspects of feminist empowerment in these two poems, despite the time gap between them, and how well women's search of self-empowerment has improved over time. These poets expressed their discomfort in contemplating their poetic identities, a notion that often destabilized their efforts as writers. The poems will be closely read, interpreted and analyzed in light of women's empowerment. It is found that women have been struggling to maintain a sense of equality in terms of being heard, acknowledged and allowed to function hand in hand with man. Al-Sabah was capable to break her silence by combating the societal and religious constraints which the patriarchal world has created to abuse and maintain their power over women. Likewise, Bradstreet managed to speak up by establishing an intellectual home for herself. By and large, the two works have granted their feminist authors an authority to enter into the academic and intellectual literary spheres that enabled them to free their pens from man's domination.
\end{abstract}

Keywords Empowerment, Suppressed Voices, Men's Made-Up Religion, Feminism, Suad Al-Sabah, Anne Bradstreet, Intellectual Home

\section{Introduction}

Women's voices have been long ignored, silenced and suppressed due to their gender, a notion Noman and Asthana (2015) attributed to women's "social structure” (p. 494), especially after the "greater freedom of expression and advance of human rights" (Rahbani, 2). However, before considering women's voices and/or language, we need to point out that women have always struggled to be considered human beings only (Ifechelobi, 2014: 17). In most societies, as Ifechelobi explains, the empowerment of man means the silence of women (ibid: p.17). Although some men might identify with women matters, only women could recognize the feeling of being distanced and outcast from the world which they lived in, a notion strongly emphasized by Simone de Beauvoir (1989) in The Second Sex when she stated that "the most sympathetic of men never fully comprehend women's concrete situation" (p. 5). After recognizing their rights, feminists' interests have dramatically increased. Not only have they fought for rights related to voting, making choice and being well-represented but they have grown more ambitious, seeking their intellectual and academic rights. This is why a number of feminist voices sought to disseminate their scholarship in an attempt to promote their ideals and feminine thoughts and consequently gain full empowerment.

The concept of women empowerment has become one of the widely used terms in the second half of the twentieth century and the early twenty first century. In fact, the embedded meaning of empowerment has always been centered in women's minds as a priority. That is, they perceived it as a rebellion against all of their usurped rights rather than diminutive representation and acknowledgment here and there. Empowerment, therefore, is the output 
progress of feminism from which feminists receive their decisiveness. Feminists further received their personal growth and the values of the group over the individual (as cited in Ifechelobi, 2014, p. 17). According to Chukwuma (1994), feminist movements have always sought a rejection of subservience and a search for self-importance. He states that

...feminism [is] a rejection of inferiority and a shining for recognition. It seeks to give the woman a sense of self as a worthy, effectual and contributing human being. Feminism is a reaction to such stereotypes of women which deny them a positive identity (p. ix)

Empowerment, in Mokta's words, is referred to as a "process which helps people to assert their control over the factors which affect their life" (p. 474). He further adds that the major purpose of creating this concept is to develop women by making them much aware of themselves and of their individuality, both politically and economically, to become much more productive and independent (Mokta, pp. 474-75). Shehabat (2016) defines empowerment in light of women's search of self-liberation and self-actualization while living in a patriarchal society that fully employs institutionalized religion to usurp their rights (p. 2). He concludes that those women succeeded in creating their own sense of self-liberation despite being subject to different patterns of self-annihilation and patriarchal domination. One technique to defy these kinds of oppression is, according to Judith Butler (1999), to develop women's own language in a way that fully and/or adequately represents them in an attempt to foster their political visibility rather than seeking matters that only help women survive (p.1).

In fact, the literature review for these two literary pieces together is very little. Very few studies have tackled Al-Sabah's They Say in contrast with Bradstreet's The Prologue. The reason is that the Arabic poem was not translated into English despite the powerful voice of the poet. Here, the rationale after conducting this comparison is to respond to a set of questions raised by Butler (1999) in her book Gender Trouble: Feminism and the Subversion of Identity in which she wonders whether or not women language and/or voice could create a sense of "cultural formation," and consequently lead to women's empowerment worldwide. Butler asks if there were some commonalities among "women" that preexist their oppression, or do "women" have a bond by virtue of their oppression alone? Also, she wonders if there was a specificity and integrity of women's cultural or linguistic practices always specified against and, hence, within the terms of some more dominant cultural formation? (p. 4)

It should be mentioned that the two major feminists' voices have been identified to generally respond to Butler's questions from one side and to elaborate on women's language from the other. These voices are Suad Al-Sabah, a Kuwaiti poet, and Anne Bradstreet, an American poet. Al-Sabah has always written on Arab women oppression and their inability to speak up as evidently can be seen in the current poem. Similarly, Bradstreet had always attempted to evaluate the "discomfort suffered by Puritan women in contemplating their identities" (Scheick, 1994: p.166). Despite the time gap in between the two feminist works, we expect some major commonalities between them due to the hard conditions these intellectual feminists had experienced then. The two poems below demonstrate how women's voices have defied man's dominant seniority of usurping women's intellectual rights. The contrast that will be adopted in this study will use block contrast where each unit of difference will be tackled separately.

\section{Suad M. Al-Sabah (1942- current)}

Al-Sabah was born in 1942 as a member of the ruling family in Kuwait. She has written in different areas of literature and economics and has become a professor of Economics and Political Sciences at Cairo University in 1973. She obtained a doctorate in economics from Sari Guilford University in the United Kingdom in 1981. This kind of education foreshadows part of the empowered feminist voice she has, especially when she intermingled with very powerful voices of feminists. She has numerous divans of poetry and a number of books and publications in economics (Luluah, 2010). Despite belonging to the ruling class, it was not an impossible mission for a Kuwaiti woman to create her own poetic identity, an identity that proved to be very competitive to that of the male poets.

They Say was first published in 2001 to represent the ambitions, needs and rights that repressed women have always wanted to achieve. Being a princess in Kuwait and belonging to the ruling class is in itself considered empowerment. However, women's voices have always been considered disgraceful. From the pre-Islamic era until the mid of the twentieth century, women have been depicted as objects of entertainment and recipients of love and eroticism. That is why reciting and/or composing poetry by female poets had not been allowed due to their gender. It was always believed that writing was "distinctly understood as male activity” (Scheick, 1994: p. 168). Al-Sabah, however, has broken all the societal traditions and familial norms that might have banned her from speaking up. In They Say (2001), she tackles themes related to her intellectual artistic talent and her feminist thinking ideals in which she mocks and challenges male authors and fights for her rights as a feminist poet. Challenging the patriarchal society, equipped with the cover of institutionalized religion, not only sets her free from the societal misogynist restrictions, but also makes her a source of empowerment to other powerless women.

\section{Anne Bradstreet (1612-1672)}

Anne Bradstreet, the puritan poetess, a devout Christian and the humble bonnet wearer had always been a "controversial literary figure" (Gordon, 2016: p. 2). She 
wrote more than 7000 lines of poetry that tackled great topics of history, such as "the history of the world, the current state of the sciences, the political relationship between the old and new worlds, and the many religious conundrums of puritanism" (ibid: p.3). Written posthumously, The Prologue (1650) was intended to address the place of humility women reached in the Puritan culture (Scheick, 1994: p. 169). However, many critics and writers have criticized Bradstreet for the nature of her works and, maybe, due to not having a clear-cut writing perspective that reflected her identity as a writer. Giffen (2010) wondered if Bradstreet is a "dogmatist or a rebel? Is her relationship to Puritanism exemplary or does she offer [readers] one of the earliest examples of a subversive feminist voice?” (p.1) Some scholars e.g., Gordon (2016), point out that Bradstreet used the word "fame" thirteen times in the first three works which reflects her concern as a poet who wishes to strike balance in between her stature as a poet and her anxiety as a woman who would not be allowed to take her place in the pantheon of great English poets (2016: p.3).

New (1993) harshly criticizes Bradstreet for writing in a world that is dominated by "a body of male elders." For him, Bradstreet, is, "well-apprised of the limitations of female speech" (p.100). This is mainly attributed to the notion that critics and male writers had always suggested that women should only be assigned "domestic spheres" and that they could not speak out nor act in public; simply looking at women as plights. Also, it is well-known that in the Puritan American culture, the female encounters with authority were on the whole dissimilar to male encounters. Jeffery Hammond (1993) views Bradstreet as a "naïve artist who blurts out spiritual insufficiencies in an unintended contradiction of what she wants. He states that if critics exaggerate Bradstreet's "sense of alienation from Puritan religion or society, they unintentionally undermine the artistic and psychological integrity of her work" (as cited in Giffen, 2010: p. 2). Like Hammond, Giffen (2010) expresses her wonder about the nature of works Bradstreet presented, whether or not they represent "submissive feminist voice?” (p. 1)

That said, women were not given enough intellectual privileges as their men peers when they choose to write. For example, when Susan Ferrier started writing novels, M.G. Lewis was dissatisfied and said, “...as a rule, I have an aversion, a pity and contempt, for all female scribblers. The needle, not the pen, is the instrument they should handle, and the only one they ever use dexterously" (as cited in Herzog, 1998, p.425). Due to certain practices by males, some of the females' intellectual rights have been confiscated by males, thus assigning women very limited roles within the intellectual and academic circles of the Puritan American culture. In Scheick's words, "seventeenth- and eighteenth-century women struggled with the nature of authority more personally and internally than did most of their male peers" (1994: pp.166-7).
Women, according to Lewis, could only write love letters. Similarly, Bowles sarcastically permitted women's "literary pursuits" (1802: p. 24) as long as they complied with their domestic duties. Now that we reviewed the biographies and literary careers for both poets, the differences between They Say and The Prologue are contrasted below in terms of their textual analysis and their literary backgrounds. Then, a review of the shared threads will be discussed in the conclusion.

\section{They Say (2001): Text Analysis}

The poem consists of three stanzas written in free verse; each begins with repeating the phrase, yagoloon, the title of the poem, which translates into "they say" (2001), a passive nomination for a collective male group, apparently referring to the world of patriarchy. Definitely, the target audience is the female readers who misguidedly yet unknowingly fear the dominance and superiority of men regarding their intellectual power and consequently regarding their belief in their poetic potential. In each stanza, Al-Sabah tackles how women have always suffered from questioning their own simple rights; yet they have obeyed without questioning its consequences. Then she mentions how she courageously challenges the males' intellectual despotism. In the first translated stanza below, Al-Sabah shows how major women authors, critics and scholars have always suffered from man's usurpation of their intellectual and poetic excellence. The stanza reads,

They say;

Writing is a great $\sin$...

do not then write.

And prayer before the letters is a taboo

do not even dare write!

And the poems' horizon is nothing but poison

be careful not to drink.

And here it is

I drank a lot

I did not get poisoned with the pen's ink on my office

Now here...

I have written a lot

A huge fire was set on each star

I wasn't doomed by the wrath of God

nor the prophet got accordingly mad.

The stanza above clearly hints at the threats women used to face once they opt for composing poetry to express their feelings and to forge their poetic identities. Al-Sabah's notion is that male writers, even audience, feel that women not only do not know how to compose poetry, but they also must not. The vast majority, as can be implicitly inferred, have been silenced and distanced from the intellectual and poetic area of their male counterparts without even recognizing a logical reason for being distanced. Al-Sabah mentions justifications repeatedly offered by society: taboos and societal fear, dos and don'ts (I wasn't doomed by the wrath of God? /Nor the prophet got accordingly 
mad). The latter is in fact the most significant unsaid message she intends to deliver. She wants all women to rebel against their ill-constructed identities by never unquestioning man's inevitable domination. Writing poetry by women has been considered a sin in the Arab culture for a very long time. A woman could neither go to a public gathering, pubs or academic institutions to be heard and/or to recite poetry. They were not allowed to write because it was considered a taboo (Writing is a great $\sin /$ do not then write).

Under the pretext of religion, women were oppressed unjustifiably. Therefore, Al-Sabah warns them not to surrender to man's dominant instincts. In addition to this warning, there was an unescapable punishment, i.e., "death". In a metaphor that brilliantly denotes the rhetorical empowerment, she compares women who approach the world of male-writers to those who approach poison with an ultimate consequence of death (And the poems' horizon is nothing but poison). In the last two lines, (So I was not doomed by the wrath of God? / nor the prophet accordingly got mad), she proves right that she has broken all limits and ignored warnings and, however, no harm is done to her. She concludes that by accepting the challenge of writing she still belongs to men's faith, which is highly secured. The unsaid message implies that she is still a believer, exactly like men, because she does not make any infringement with regard to God's word. Most notably, a technique she uses here is the repetition of the first-person speaker, 'I', for four times stands for Al-Sabah's emphasis on her feminist identity. In short, Man resorts to some pretexts to hinder women's progress in their intellectual journeys such as threatening not to gain God's wrath and break the prophetic traditions. She further points to how women suffer violation of their human rights men.

\section{They say;}

Writing is but a privilege of men ...

Do not even dare pronounce it,

Flirting is men's solo art...

Do not get confused!!

And that writing is a deep sea water

Do not be overwhelmed ...

And behold, I have loved much ...

And behold, I have swum much ...

I resisted all the seas and did not sink..

Al-Sabah mocks, yet motivates, women who respond to the threat of men in different social life and literary aspects, namely love and writing. These two aspects represent both an academic aspect and a romantic one. For women, love and writing were considered taboos because only men were authorized to practice them (Writing is but a privilege of men/ Do not even dare pronounce it). Apparently, Al-Sabah's main target audience are women whose intellectual and sexual identities are usurped. For her, men are allowed to write and flirt but women are not (Flirting is men's solo art). She emphasizes the notion of intimidating women to approach these two areas because of the inevitable plague awaiting for them, poison and/or death. Al-Sabah compares women who ventures to write to those who want to swim in a deep risky ocean implying unavoidable drowning (And that writing is a deep sea water). Literally speaking, Al-Sabah encourages all women to practice their feminist and intellectual rituals regardless of men's despotic authority by inviting them to take advantage of her own experience (I resisted all the seas and did not sink).

Drawing upon the same theme, Al-Sabah courageously invites talented women to benefit from her personal experience in writing and (metaphorically) swimming up the current, counterarguing men's ever-monopolized literary world, yet without being emotionally hurt. On the contrary, she has gained more empowerment both socially and intellectually by speaking up. This model of challenge resembles New's perspective (1993) in which she depicts women who are "threatening, toppling and/or replacing the outward forms of patriarchy" (p. 101). It is worth mentioning that there are a few explicit messages where Al-Sabah raises women's spirits to imitate her diligent efforts in challenging men. She also calls for a rebellion against the patriarchal authority by freeing women's pens. In the meantime, she provides them with a sense of peace (Do not be overwhelmed/and behold, I have loved much/and behold, I have swum much/resisted all the seas and did not sink). Given this compelling empowerment of the intellectual voice, it is evident that Al-Sabah has experienced "swells of resistance" by both men and women yet without worrying at all (Scheick, 1994: p.167). Then, Al-Sabah keeps her challenge. She maintains,

They say:

I broke with my poetry the wall of virtue

And deconstructed the notion "men are poets"

How come a poet be born in the tribe?

I laugh at all this nonsense

and I mock those who want in the era of the planetary war.

Women be buried alive

I ask myself;

Why is male singing permissible?

When women's voice becomes his vice?

Here, Al-Sabah amazingly announces her triumph. She announces that she deconstructed the notion that men are the exclusive poets in her tribe, referring to the notion that men, almost in the Arab world, enjoy more privileges than women. They can do whatever they want to do whereas women are not allowed to. A male Arab can travel abroad to pursue higher degrees alone and also they can courageously recite poetry in public. Poetry for males is a sign of honor and prestige but for females it is a sign of disgrace. A turning point has taken place here banning such tribes, which represent patriarchy, to suppress women's poetic talents (broke with my poetry the wall of virtue/and deconstructed the notion "men are poets"). For her, she 
does not care if she violates the virtuous world of traditions and norms as long as she attains her lifelong ambition i.e., freeing her pen. She sums up the strong points that demonstrate her own empowerment: the intellectual home and/or sphere she carved for herself amidst the world of men who always had ill-thoughts about women's poetic careers and her carelessness about the inevitable fate and consequences for challenging men's word. Al-Sabah's final laughter denotes much more empowerment and victory. Below, the second poem provides a different empowering voice (I laugh at all this nonsense/and I mock those who want in the era of the planetary war).

\section{The Prologue (1650): Text Analysis}

The poem consists of eight stanzas; each stanza consists of six lines in which Bradstreet elaborates on two major notions: her confession about her inferior feminist poetic identity and a sense of humility. She reasons to gain more empowerment from men and hence speaks a powerful voice that enables her to represent the voice of women, especially that she was the first American poet. In the first stanza, she says,

To sing of Wars, of Captains, and of Kings,

Of Cities founded, Common-wealths begun,

For my mean Pen are too superior things;

Or how they all, or each their dates have run,

Let Poets and Historians set these forth.

My obscure lines shall not so dim their worth.

From the very beginning of the poem, it is clear that the Bradstreetan lexical choice of words and expressions stands for a low-esteemed character and an underestimated self. The adjectives in the poem excerpt display the state of inferiority and humility she found herself staggering in. The two negative adjectives "mean" and "obscure" describe women's writing and denote a low level of writing. They do not predict a strong start for the first American feminist in the seventeenth century, who was supposed to be equipped with a very strong voice instead of showing weakness and inferiority. In the excerpt above, Bradstreet confesses that she is not like great historians, poets and critics to tackle great major topics and themes nor was she proficient to write about great political events, figures, wars, commonwealths and major themes. This humility may well sound unjustified (Let Poets and Historians set these forth/my obscure lines shall not so dim their worth). It does not correspond to feminists' ambitions and contradicts with their wish to challenge and break their silence, instead of being submissive. If readers think of the literal denotation of Bradstreet's words, they feel she is not concerned with future ambitions of women and is only interested in remaining intellectually impotent and dependent on male-oriented scholarship. In short, she says that due to her humble knowledge and immature genuine poetic and literary potential, she gives the floor for male writers and historians while she tackles topics and themes that suit her feminine nature. She further states, But when my wond'ring eyes and envious heart Great Bartas' sugar'd lines do but read o'er, Fool, I do grudge the Muses did not part 'Twixt him and me that over-fluent store. A Bartas can do what a Bartas will But simple I according to my skill.

Once again, she falls a victim beyond her feminist expectations that require her not to surrender to man's increasing ego; a shortcoming often registered against Bradstreet by critics and feminists who look at the surface meaning and value of Bradstreet's expressions. In the last two concluding verses, Bradstreet confesses that she only acts in accordance with the humble limits and space assigned to her, unlike the great Bartas who was a courtier, poet and a doctor of law at that time (A Bartas can do what a Bartas will/ But simple I according to my skill). In other words, her works, along with other feminist ambitions, had never been comparable to those of men, thus remaining very simple because of being far away from the domain of Bartas. After repeatedly confessing her humble potential in comparison with that of men (Fool, I do grudge the Muses did not part/'Twixt him and me that over-fluent store), one feels that she had been serious in depicting the current literary submissiveness and humility she, among other women, suffered from. Here, alluding to Muses is positive yet submissive.

Much has been said about Bradstreet's view of her literary works. That is, she keeps underestimating her feminine fictive potentials by stating that she is unable to cope up with the supernatural powers revealed to men. However, much empowerment can be felt in her poetry. One can read a sense of obscurity and meanness that viewed Bradstreet's pen in the first stanza. Also, one can easily capture the idea that her pen is very simple compared to that of great Bartas, a feeling that made her depend on her own skill rather than being jealous from Bartas in search of acknowledgment. Only at this point readers will feel the decisiveness and independence she had to become herself, consequently achieving her poetic identity through the lenses of her male accusers. She comments on the irreparable artistic state of writing women like herself. She maintains,

From School-boy's tongue no Rhet'ric we expect,

Nor yet a sweet Consort from broken strings,

Nor perfect beauty where's a main defect.

My foolish, broken, blemished Muse so sings,

And this to mend, alas, no Art is able,

'Cause Nature made it so irreparable.

Notably, Bradstreet keeps playing with words back and forth, not giving a clear-cut evidence about her own poetic status. In the previous excerpt, she partly blames the Muses, or, in a larger sense, God, for not providing her with the talents and gifts given to male peers and partly blaming her gender (Fool, I do grudge the Muses did not part). In 
another humiliating metaphor, she blames those who expect much from her pen when they are fully cognizant that her skill is very humble, like an immature school boy who has no literary potential to compose rhetorical poetry due to his age (My foolish, broken, blemished Muse so sings). In other words, she says that she is a beginner in her writing skill because she does not possess this skill, advertently pointing to a great distance between men's artistic potential and her own. As she comes to blame nature, she accuses the biology of women as being the major reason for the state of submissiveness, as if such qualities were inherited and can never be repaired (Cause Nature made it so irreparable). Biologically speaking, being a female means being weak and submissive. The linguistic choice of expressions (e.g., school-boy's tongue, broken strings, and foolish, broken, blemished Muse) essentially supports the idea that women's disempowered potentials were attributed to genetic and biological factors originated by the nature of their gender. The sorrow and hopelessness readers feel in the last two verses in the stanza support the previous argument of a feminist poet who, despite the empowerment given to her, insists on underestimating her poetic career, thus reflecting negatively on a whole generation who had suffered a lot from being unable to speak up nor to make their voices heard. She maintains,

Nor can I, like that fluent sweet-tongued Greek

Who lisp'd at first, in future times speak plain.

By Art he gladly found what he did seek,

A full requital of his striving pain.

Art can do much, but this maxim's most sure:

A weak or wounded brain admits no cure.

In the above stanza, Bradstreet alludes to the Greek orator Demosthenes who used to have a speech impediment when he was a teenager. By skill and practice, he later became a very famous orator with a great reputation that made him forget all the pains and flaws in his life. As for Bradstreet, resorting to art to heal her lifelong feminist pains and flaws was inappropriate due to certain physical and biological defects in her brain, both being weak and wounded (A weak or wounded brain admits no cure). Seemingly, this stanza is the last in which she views herself as incapable and poetically disempowered to ascend high like the great Greek ancestors who paved their way by skillfully deploying their literary conventions. She, in contrast, couldn't get rid of her pains and defects. She rotates in her style between submissiveness and empowerment. Below, she expresses her anger and dissatisfaction with men who underestimate women's distinction and excellence.

I am obnoxious to each carping tongue

Who says my hand a needle better fits.

A Poet's Pen all scorn I should thus wrong,

For such despite they cast on female wits.

If what I do prove well, it won't advance,

They'll say it's stol'n, or else it was by chance.
Here, Bradstreet turns to another phase in which she stops humility and speaks in light of criticizing "the other", hinting at her accusers, by saying that she abhors whoever belittles her and/or their female wits by claiming they only fit to serve in domestic spheres e.g., sewing and kitchen (I am obnoxious to each carping tongue/ Who says my hand a needle better fits). She not only criticizes her accusers but she hints at the embedded "female wits" that she never mentioned previously. She apparently depends on "female wits" to prove to the other that she brilliantly meets the demands of any positions she aspires to if given a chance e.g., writing poetry, rather than only being assigned to domestic roles in the kitchen and babysitting. Here is the cutting edge where she goes from seeking acknowledgment and recognition for women's canonical works into refuting man's own definition of them (I am obnoxious to each carping tongue/ Who says my hand a needle better fits).

In the following excerpt, she openly blames her accusers for underestimating women's canonical works in the name of gender and social roles. She rejects the way they look down at women's prodigal literary talents. Being "obnoxious" to her accusers is another form of empowerment as she explicitly loathes those who underestimate and/or strip her off her feminist poetic traditions.

But sure the antique Greeks were far more mild, Else of our Sex, why feigned they those nine And poesy made Calliope's own child? So 'mongst the rest they placed the Arts divine, But this weak knot they will full soon untie. The Greeks did nought but play the fools and lie.

In the stanza above, Bradstreet does not come across as peaceful. The tone and language have dramatically differed (But sure the antique Greeks were far more mild/ Else of our Sex, why feigned they those nine/ and poesy made Calliope's own child?). She moves from the state of belittlement and humility into the state of criticism. She openly criticizes the ancient Greeks who were not cognizant of the other sex, dedicating the nine Muses for their male services rather than serving their female partners (So 'mongst the rest they placed the Arts divine/ But this weak knot they will full soon untie). She later illustrates an example of Calliope, the Goddess of poetry, who is a woman representing the epic poetry and who adopts poetry as if it were her child. By so doing, she shows an intimate and inseparable relationship between the mother, Calliope, and her child, poetry. Here, it is evident that the mentioning of Calliope parallels with the previous Demosthenes, the great orator, as both have a commonality of utilizing poetry for the sake of their own genders. Once again, she concludes the sixth stanza by mocking her opponents and describing them as foolish and liars due to being unable to untie the "knot" or the argument she posed. She maintains,

Let Greeks be Greeks, and Women what they are.

Men have precedency and still excel; 
It is but vain unjustly to wage war.

Men can do best, and Women know it well.

Preeminence in all and each is yours;

Yet grant some small acknowledgement of ours.

In the stanza above, she arrives at a conclusion; she decides that despite all her criticism of the Greeks and her male opponents, she confesses that the Greeks should maintain their current precedent status and their superiority. Likewise, women should surrender to this state of inferiority and should never wage a useless war in response. War is not significant at this point because it will lead to more degradation and ignorance of women's poetic talents. In other words, she grants men their dominance, superiority and authority but to grant her acknowledgment in return. However, one can also read the excerpt above differently. The verse " men can do best, and women know it well," stands for, as McElrath puts it, a defensive concession that the ability to write was generally perceived as a male property, thus making "women who ventured into writing doubtlessly experienced some uncertainty of authorization, an authority exacerbated by male control over literary genres” (as cited in Scheick, 1994:168). Here, seeking acknowledgment stems from a powerful and self-confident persona. It stands for excellence, dedication and self-confidence. Bradstreet explicitly assures her readers that her writings are not intended to challenge men's wits or their precedency; rather, they are intended to prove that whatever may succeed in her verse is not either by chance or plagiarism (ibid: p.168). The acknowledgment Bradstreet seeks recurs the theme of smart submissiveness which eventually helps women speak up and make their voices heard. This notion is emphasized by Bradstreet's choice of "small" to describe acknowledgment, a feature that Scheick reads as a "conscious authorial intention" (1994:p. 169). Finally, Bradstreet concludes that

And oh ye high flown quills that soar the skies,

And ever with your prey still catch your praise,

If e'er you deign these lowly lines your eyes,

Give thyme or Parsley wreath, I ask no Bays.

This mean and unrefined ore of mine

Will make your glist'ring gold but more to shine.

In the end, Bradstreet demonstrates an eloquent metaphor by comparing poets to birds of feathers, while feathers metaphorically refer to a pen which is the major point of conflict here. The same image also stands for the physical power men seek that will automatically bring them praise. Once again, she peacefully seeks acknowledgment, literally referring to men as "high flown quills," meaning that they are worth of praise, glory and superiority. She, as a spokesperson of women, asks for just "thyme or parsley" when she refers to cheap herbs but very powerful ones that heal people quickly. Here, she points out that we can create great things from tiny-tiny objects (Give thyme or Parsley wreath, I ask no Bays). Even though "thyme or parsley" may look very simple and cheap, but for her they look like an acknowledgment and/or an award for women. Once again, the final stanza indicates the position or the status women seek; they seek no physical or material empowerment. Rather, she is seeking a spiritual empowerment, believing that spiritual and/or intellectual empowerment is meaningful and effective. Now that the textual analysis of the two poems is finished, general literary backgrounds and thematic debates will be provided.

\section{They Say: Literary Background}

Unfortunately, very little scholarship has been written about Al-Sabah's They Say. Nonetheless, once the poem is comprehended and analyzed many themes could be inferred. A major theme that can be captured from reading Al-Sabah's They Say is the theme of 'the unsaid,' where she inconspicuously refers to many practices women never valued. Al-Sabah hints at many practices women used to do that she, among others, thinks of as disgraceful and inhuman, such as doing housework day and night and taking care of children. This stems from the laborious way of bringing up their children and the responsibility they take in return. Another major theme Al-Sabah explicitly pointed out is women's inability to explicitly express their emotions once they fell in love whereas men can speak about how they court and flirt. In contrast, if girls do so, they will definitely be harshly punished.

However, after reading They Say for the first time, one feels its tone of intellectual and spiritual empowerment. The Poem has the tone of rebelliousness, enthusiasm and challenge equipped with sarcasm which is intentionally meant to mock women and to inform them that their state of inferiority is not justified. Written with a sarcastic tone, the musical devices employed in the poem e.g., the rhythm and the rhyme, help resurrect hope and ambition for women by transforming them from women-for-kitchen into ambitious and dependent. Speaking of the translation of Al-Sabah's work with regard to voice and empowerment, the present researcher opted for literal translation in an attempt to capture the content, form, as well as the spirit of the poem.

\section{The Prologue: Literary Background}

A major theme that can be elicited from The Prologue is Bradstreet's inability, as a feminist poetess, to be involved in the circle of great historians, critics and poets who had been capable to compose poetry about the major incidents in life. So, the major theme in The Prologue is to make her feminist poetic voice heard and acknowledged. Furthermore, she aspires to heal her intellectual inferiority state when compared to her male peers who always look down at her excellence and her canonical literary works. The tone Bradstreet employed is entirely negative and does not match with the principles of feminist movements that call for empowered voices and powerful feminist 
languages.

The technique of humility and submissiveness Bradstreet employed is intended to gain her acknowledgment, to give her access to intellectual and spiritual spaces and to enable her recite poetry in public spheres. At this point, she truly gets this acknowledgment verily by playing with the emotions of her male accusers, who used to suppress her pen and depict it in light of her gender. Gordon argues that Bradstreet was cognizant that women's words held political threat" and that she wrote poetry that reflected a very strong sense of identity, self-assertion and self-actualization (2016: p. 3). Gordon further points out that when one reads Bradstreet's The Prologue, they will find that her work is "replete with double meanings and ironies, self-depreciation and self-condemnation-strategies she had learned in a culture that disparaged women for trespassing in realms that were considered men territory" (ibid: p.4). Such strategies, by and large, have gained her a strong voice. Her poetry not only made readers respect her struggle in silence to get to her goals, but it also revealed the means she employed to prove her accusers wrong. Arora (2017) further comments on the argument above by saying that, her poetry makes us recognize her as a confident female poet who produced work that boasted of her experiences and by giving them value in a society that silences it diligently, she presented her strong sense of self along with her resilient struggle for self-assertion and for subjectivity, autonomy and creativity" (para. 2).

The Prologue sheds light on the worthiness of Bradstreet's pen but in a very humble yet humiliating manner. Here, like Al-Sabah, Bradstreet challenges the conventions underneath the view of conformity to the norms and by using her indisputable belief in God as a sanction to write. She makes a powerful statement by using her pen as a weapon. Arora (2017) points out that Bradstreet adopted a tone that is equipped with "self-derision and parody coupled with modesty." (ibid: para, 6) To achieve this, she resorted to a straightforward and simple language. At this point, a major commonality between Al-Sabah and Bradstreet is their belief in God's protection for them to write in times when writing was considered a taboo for women.

Reviewing both poems, we infer that Bradstreet, unlike Al-Sabah, had always sought a voice that enabled her to implicitly deliver her feminist messages through self-effacement due to the women's oppressed status within the Puritan American culture. Written in response to the place of humility, Bradstreet found herself staggering amidst the Puritan culture male-dominated world and was able to consciously convert her emotions and feelings about seeking men's acknowledgment to an artifice and a rational, yet ironic, discourse that contains feelings of empowerment perfectly (Scheick, 1994: p.169). In contrast, Al-Sabah has resorted to a voice that challenges the patriarchal and socioreligious conventions and help intellects’ ways to break their silence.

\section{Conclusions}

It can be noticed that the two poets represent two different types of empowerment. Both poets had a strong belief that the only solution to gain intellectual and poetic empowerment is by liberating their pen: to gain acknowledgment and to create intellectual and spiritual space that entitle them to speak in public spheres rather than to keep them limited to domestic spheres. While Al-Sabah explicitly expresses her feminist empowerment through challenging the patriarchal and religious conventions, as well as men's own literary conventions, Bradstreet resorts to an unsaid, yet as empowered as Al-Sabah's voice. Or to be more precise, she resorted to this technique to create a feminist-empowered space to enable her to function in public spiritual and intellectual spheres rather than remain in the male-dominated spheres. Al-Sabah's poetry has been described as a model that aims at "threatening, toppling and/or replacing the outward forms of patriarchy” (New, 101). At face value, one can easily infer that Al-Sabah has created her own intellectual and spiritual space and thus has become more powerful through her influential poetic talent. Her voice has become much more recognized than her peer-writing women. She shows no submissiveness or humility to make her voice heard. Unlike Al-Sabah, who succeeded in appreciating her female feminist role in crossing the borders of patriarchy, Bradstreet had always been described as a model of womanly patience, a notion most (especially radical) feminists would refuse.

What Bradstreet, as a feminist advocate, failed to appreciate was understanding her feminine power as the first American female poet: begging for an acknowledgment from the ever-dominant patriarchy. Yet, critics praised her for her smart, female-status-fitting techniques through which she was able to create her own spiritual and intellectual space. All in all, despite the fact that Al-Sabah and Bradstreet had been acting under the umbrella of institutionalized religions represented by both fundamentalists and Calvinists, respectively, they succeeded in creating new models of empowerment.

\section{REFERENCES}

[1] Al-Sabah, S. (2001) Selections from the Poetry of Suad Al Sabah. Egypt: The General Egyptian Committee for books.

[2] Arora, S. (2017). “An Analysis of Anne Bradstreet's Prologue”. A Room for One’s Own: An Analytical Literature Blog. Retrieved from https://simran78arora/ wordpress.com 2017/12/22/an-analysis-of-Anne-Bradstreet-prologue.

[3] Bill and Melinda Gates Foundation. (2016). A Conceptual 
Model of Women and Girls’ Empowerment. Retrieved from https://docs.gatesfoundation.org/Documents/BMGF_Empo wermentModel.pdf.

[4] Beauvoir, S. (1989) The Second Sex. New York: Vintage Books.

[5] Bowles, J. (1802) "Remarks on Modern Female Manners, as distinguished by indifference to Character, and Indecency of Dress”. London, P.24.

[6] Bradstreet, A. (1981) The Complete Works of Anne Bradstreet. Joseph R. McEllrath, Jr. and Robb A. P. (editors). Boston: Twayne Publishers.

[7] Butler, J. (1999). Gender Trouble: Feminism and the Subversion of Identity. New York: Routledge.

[8] Cecilia, L. Quiroz, S. Scruton, C. and Bird, K. (2009). "Understanding and Operationalizing Empowerment" Overseas Development Institute. Retrieved from https://www.odi.org/sites/odi.org.uk/files/odi-assets/publica tions-opinion-files/5500.pdf.

[9] Chukwuma, H. (Ed.) (1994). Feminism in African literature. Enugu: New Generation Books.

[10] Giffen, A. (2010) "Let no man know": Negotiating the Gendered Discourse of Affliction in Anne Bradstreet's "Here Follows Some Verse Upon the Burning of Our House, July $10^{\text {th }}, 1666$ ”. Legacy, 27(1): pp. 1-22.

[11] Gordon, C. (2016). "Humble Assumptions: The True Story of Anne Bradstreet's The Tenth Muse”. Journal of Early American Life. 16 (3).
[12] Herzog, D. (1998). Poisoning the Minds of the Lower Orders. Princeton University Press: New Jersey.

[13] Ifechelobi, J. N. (2014) "Feminism: Silence and Voicelessness as Tools of Patriarchy in Chimamanda Adichie’s Purple Hibiscus.” African Research Review. 8 (4), 17-27.

[14] Luluah, A. (2010). Blackbird Archive: Souad Al-Mubarak Al-Sabah. 9 (2) Retrieved from https://blackbird.vcu.edu/v9 n2/poetry_gulf/al-mubarak_al-sabah_s/index.shtml.

[15] Mokta, M. (2014). "Empowerment of Women in India" Indian Journal of Public Administration. Vol Lx (3) pp. 474-479.

[16] New, E. (1993). "Feminist Invisibility the Examples of Anne Bradstreet and Anne Hutchinson”. Common Knowledge 2(1): 99-117.

[17] Noman, A. and Asthana, S. (2015). "Women Voice in the Arab-American Literature.” LangLit 2(1) pp.494-503.

[18] Rahbani, L. N. (2010). Women in Arab Media: Present but not Heard. California, Stratford University.

[19] Scheick, W.J. (1994). "Logonomic Conflict in Anne Bradstreet's "A Letter to Husband”" Essays in Literature; Macomb 21(2), 166-186.

[20] Shehabat, A. (2016). "Women Empowerment in the Realms of Institutionalized Religion and Patriarchy: El Saadawi’s Firdaus and Yezierska's Sara as Examples”. International Journal of Applied Linguistics and English Literature. 5(5) $1-5$. 